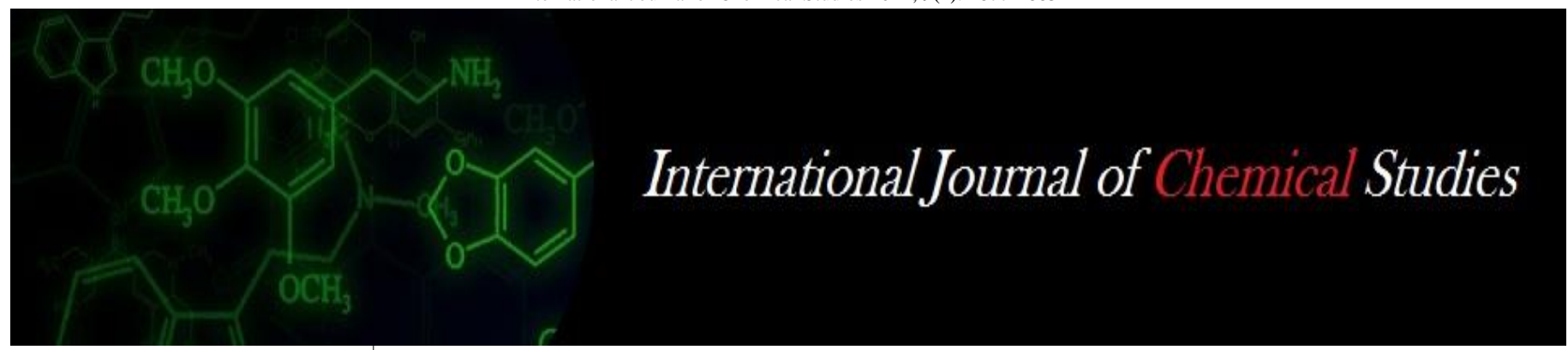

P-ISSN: 2349-8528

E-ISSN: 2321-4902

www.chemijournal.com

IJCS 2021; 9(1): 2877-2883

(C) 2021 IJCS

Received: 15-10-2020

Accepted: 27-12-2020

Lawate Pramod Ulhas

Department of Agronomy,

Institute of Agricultural

Sciences, Banaras Hindu

University, Varanasi, Uttar

Pradesh, India

\section{SK Prasad}

Department of Agronomy, Institute of Agricultural Sciences, Banaras Hindu

University, Varanasi, Uttar Pradesh, India
Corresponding Author: Lawate Pramod Ulhas Department of Agronomy, Institute of Agricultural Sciences, Banaras Hindu University, Varanasi, Uttar Pradesh, India

\section{Effect of irrigation scheduling and zinc fertilization on growth and soil chemical properties under irrigated wheat (Triticum aestivum $\mathbf{L}$.) cultivation}

\section{Lawate Pramod Ulhas and SK Prasad}

DOI: $\underline{\text { https://doi.org/10.22271/chemi.2021.v9.i1an.11669 }}$

\begin{abstract}
A field experiment was conducted to assess the effect of irrigation scheduling and zinc fertilization on growth and yield of wheat. The experiment was conducted at agricultural farm of Institute of Agricultural Sciences, Banaras Hindu University, Varanasi, India during 2014-2015 and 2015-2016, respectively. The treatments consisted of four irrigation scheduling intervals $\left(\mathrm{I}_{1}-\mathrm{CRI}+\right.$ Late Tillering + Flowering, $\mathrm{I}_{2}-\mathrm{CRI}$ + Late Jointing + Milking, $\mathrm{I}_{3}-\mathrm{CRI}+$ Flowering + Dough and $\mathrm{I}_{3}-\mathrm{CRI}+$ Milking + Dough) and five zinc fertilization doses at different stages of crop growth. The results indicated that irrigation scheduling and zinc fertilization significantly influenced plant height, crop growth rate (CGR), ear length and test weight. There was no significant variation in $\mathrm{pH}$, EC, organic carbon and zinc with the irrigation scheduling interval. Application of zinc had significant increase in zinc content in soil. However, there was non-significant effect of irrigation scheduling and zinc fertilization on relative growth rate (RGR), net assimilation rate (NAR). On the basis of findings of two years experimentation, irrigation scheduling at CRI + Late Jointing+ Milking and zinc fertilization @ $10 \mathrm{~kg} \mathrm{Zn} \mathrm{ha}^{-1}$ as basal $+0.25 \% \mathrm{ZnSO}_{4}$ foliar spray at $\mathrm{Z} 45+0.25 \%$ spray at $\mathrm{Z} 71$ stages of wheat is recommended for wheat growth.
\end{abstract}

Keywords: Irrigation scheduling, zinc fertilization, growth, wheat

\section{Introduction}

Irrigation scheduling becoming more important in recent years due to continuous decrease in available fresh water for agricultural production (Cai and Rosegrant, 2003) ${ }^{[6]}$. The low water productivity in farmer's fields compared with well-managed experimental sites also indicates the need more efforts to transfer water saving technologies to the farmers (Singh et al. 2014) [19, 22]. Proper irrigation scheduling is essential for the efficient use of water, energy and other production inputs. There are various approaches for scheduling irrigation, however, critical growth stage is one of the easy and simple approach of irrigation scheduling. Further it has been reported that skipping irrigation at different growth stages of wheat affect its yield components, yield as well as chemical properties (El-Gawad et al. 1993 and Sharaan et al. $2000)^{[8,21]}$. In terms of quality, skipping irrigation at milk and grain filling stage decreased moisture, fat and carbohydrate contents but gave the highest values of protein, ash and fibre contents in wheat (Mehasen et al. 2014) ${ }^{[16]}$. Thus proper irrigation scheduling neither decrease neither yield nor quality of wheat, but improve the growth, development and production of wheat (Muhammad et al. 1997) ${ }^{[17]}$. Hence, there is a need to refine irrigation scheduling to wheat by forcing a shift from plentiful to limited water.

About $30 \%$ of the cultivated soils of the world are $\mathrm{Zn}$ deficient and about $50 \%$ of the soils used for cereal crop production have low levels of Zn available for plants (Welch 1993) ${ }^{[24]}$. It is estimated; more than $40 \%$ of the wheat crop is cultivated on severely low $\mathrm{Zn}$ soils (Alloway 2008) ${ }^{[3]}$, which produces grain yields with poor $\mathrm{Zn}$ content. About two billion of the world population is affected by $\mathrm{Zn}$ deficiency (Cakmak et al. 2010a) ${ }^{[7]}$ which is associated with low dietary intake. Since cereal grains have inherently low Zn concentrations compared to legume, growing them on these potentially $\mathrm{Zn}$-deficient soils further decreases grain $\mathrm{Zn}$ concentration. It is, therefore, not surprising that the well-documented $\mathrm{Zn}$ deficiency problem in humans occurs predominantly in the countries/regions such as India, China, Pakistan and Turkey 
where soils are low in available $\mathrm{Zn}$ and cereals are the major source of calorie intake (Alloway, 2008) ${ }^{[3]}$. Increasing $\mathrm{Zn}$ concentration in wheat, staple food crop, is therefore, an important humanitarian challenge to world.

Enrichment of seeds with $\mathrm{Zn}$ benefits both crop production and health of the consumers, especially those whose $\mathrm{Zn}$ intake comes primarily from cereal grains. In wheat, it was found that the highest $\mathrm{Zn}$ concentration in seed was achieved when foliar $\mathrm{Zn}$ was applied after the flowering stage (Zadoks scale 7; Zadok et al. 1974) ${ }^{[25]}$ compared to the applications before the flowering stage (Cakmak et al. 2010a) ${ }^{[7]}$. But foliar Zn applications of $\mathrm{Zn}$ are also used, usually at the mid tillering or at early anthesis stages of growth (Cakmak et al. 2010a) ${ }^{[7]}$. Foliar application of $\mathrm{Zn}$ fertilizers is an effective agronomical practice in crop production, with substantial influence on both yield and particularly grain quality (Khoshgoftarmanesh et al. 2010) ${ }^{[15]}$. Owing to the above points a study was conducted to assess the effect of irrigation scheduling and zinc fertilization on growth and protein yield of wheat.

\section{Materials and Methods \\ Study area}

Field experiments were conducted during 2014-15 and 201516 (rabi) at Agricultural Research Farm, Institute of Agricultural Sciences, Banaras Hindu University, Varanasi, Uttar Pradesh, India. The geographical position of the farm lies at $25^{\circ} 18^{\prime} \mathrm{N}$ latitude, $88^{\circ} 36^{\prime} \mathrm{E}$ latitude and at an altitude of 128.93 meter above the mean sea level. The climate of the study site was semi-arid to sub humid with moisture deficit index between 20-40. The total rainfall of $131.30 \mathrm{~mm}$ was received during the wheat crop growth period of first (201415) year, was higher $(46.30 \mathrm{~mm})$ than second $(2015-16)$ year. The weekly mean maximum temperature ranged from 27.8 to $36.6^{\circ} \mathrm{C}$ with an average of $25.8^{\circ} \mathrm{C}$ in $2014-15$, and 28.4 to $41.4^{\circ} \mathrm{C}$ with an average of $28.8{ }^{\circ} \mathrm{C}$ in $2015-16$, during wheat growth seasons, respectively. The weekly mean minimum temperature was ranged from 6.2 to $20.9^{\circ} \mathrm{C}$ with an average of $12.8^{\circ} \mathrm{C}$ in $2014-15$ and 7.2 to $23.1^{\circ} \mathrm{C}$ with an average with an average of $13.6{ }^{\circ} \mathrm{C}$ in $2015-16$ during wheat crop season, respectively. The experimental field was typically a medium soil, suitable for wheat crop in Rabi season with homogeneously fertile with even topography and uniform textural make up. For timely and regular irrigation, the experimental field was connected to main channel of the tube well. Proper drainage facility was also provided in order to remove excess water during experimental period.

\section{Experimental material}

Wheat crop variety for experiment was used of HUW-234 (Malaviya Wheat). It was suitable for late sown irrigated conditions, having $90-100 \mathrm{~cm}$ height. It is mostly grown for bread purpose with protein content of $10-11 \%$. It completes its life cycle in 125-135 DAS. Average yield potential is 30$35 \mathrm{qtl} \mathrm{ha}^{-1}$.

\section{Experimental design and treatments}

Field experiments were set up in randomized block design (RBD) taking 20 treatment combinations and three replications. Treatments included four irrigation schedule and five levels of zinc fertilization

Table 1: Irrigation scheduling and Zinc fertilization

\begin{tabular}{|c|c|c|}
\hline $\mathbf{A}$ & \multicolumn{2}{|l|}{ Irrigation scheduling } \\
\hline 1 & CRI + Late tillering + Flowering & $\mathrm{I}_{1}$ \\
\hline 2 & CRI + Late Jointing + Milking & $\mathrm{I}_{2}$ \\
\hline 3 & CRI + Flowering + Dough & $\mathrm{I}_{3}$ \\
\hline 4 & CRI + Milking + Dough & $\mathrm{I}_{4}$ \\
\hline $\mathbf{B}$ & Zinc fertilization & \\
\hline 1 & $0 \mathrm{~kg} \mathrm{Zn} \mathrm{ha}^{-1}$ (control) & $\mathrm{Zn}_{1}$ \\
\hline 2 & $5 \mathrm{~kg} \mathrm{Zn} \mathrm{ha}^{-1}$ at basal $+0.25 \% \mathrm{ZnSO}_{4}$ foliar spray at $\mathrm{Z}_{45}+0.25 \%$ at $\mathrm{Z}_{71}$ & $\mathrm{Zn}_{2}$ \\
\hline 3 & $5 \mathrm{~kg} \mathrm{Zn} \mathrm{ha}^{-1}$ at basal $+0.25 \% \mathrm{ZnSO}_{4}$ foliar spray at $\mathrm{Z}_{60}+0.25 \%$ at $\mathrm{Z}_{83}$ & $\mathrm{Zn}_{3}$ \\
\hline 4 & $10 \mathrm{~kg} \mathrm{Zn} \mathrm{ha}^{-1}$ at basal $+0.25 \% \mathrm{ZnSO}_{4}$ foliar spray at $\mathrm{Z}_{45}+0.25 \%$ spray at $\mathrm{Z}_{71}$. & $\mathrm{Zn}_{4}$ \\
\hline 5 & $10 \mathrm{~kg} \mathrm{Zn} \mathrm{ha}^{-1}$ at basal $+0.25 \% \mathrm{ZnSO}_{4}$ foliar spray at $Z_{60}+0.25 \%$ spray at $Z_{83}$. & $\mathrm{Zn}_{5}$ \\
\hline
\end{tabular}

Note: $Z$ = Zadok's scale, Z45 = Boot swollen, $Z_{60}=$ Pollination (Anthesis), $Z_{71}=$ Dough stage, Z83 = Early dough

A plot having uniform fertility and uniform topography were selected for running of field trials in both years. The crop stubbles of previous crop and weeds were removed and destroyed from the field at the time of land preparation. The recommended rate of nutrients $(\mathrm{N}, \mathrm{P}$, and $\mathrm{K} @ 150,60$, and $60 \mathrm{~kg} \mathrm{ha}^{-1}$ ) were applied through urea, DAP and MoP. DAP and MoP were applied at the time of sowing whereas, nitrogen in two splits i.e. $1 / 2$ at sowing and $1 / 2$ at 30 days after sowing. Zinc was applied as a basal dose according to treatments through zinc sulphate (monohydrate) just prior to sowing of wheat. Line sowing was followed in furrows, opened by wooden marker at $22.5 \mathrm{~cm}$ as row spacing by using $125 \mathrm{~kg}$ seeds ha ${ }^{-1}$ and furrow were covered immediately after sowing. Quantity of water applied in field was measured with parshall flume by properly placing in water channel and delivered to the respective plots as per the irrigation schedule. Volume method was used to measure the irrigation water. The depth of irrigation was $6 \pm 2 \mathrm{~cm}$. Irrigations were scheduled at predetermined critical growth stages of crop in respective treatments.

\section{Collection of experimental data Plant height (cm.)}

Height of five randomly selected plants were recorded at 30, 60,90 DAS and at harvesting stage from base of the plant to tip of the crop.

\section{Crop growth rate (CGR)}

It is the rate of the dry matter production per unit ground area per unit time and it was computed by using formula suggested by Watson 1952. It was expressed in $\mathrm{g} \mathrm{dm}^{-2} \mathrm{day}^{-1}$.

$$
\mathrm{CGR}=\frac{\mathrm{W}_{2}-\mathrm{W}_{1}}{\mathrm{t}_{2}-\mathrm{t}_{1}} \times \frac{1}{\mathrm{~A}}
$$

\section{Where}

$\mathrm{W} 1$ = Dry weight of plant $(\mathrm{g})$ per $\mathrm{m}$ row length at time $\mathrm{t} 1$ $\mathrm{W} 2=$ Dry weight of plant $(\mathrm{g})$ per $\mathrm{m}$ row length at time $\mathrm{t} 2$ $\mathrm{A}=$ Land area $\left(\mathrm{dm}^{2}\right)$ 


\section{Relative growth rate (RGR)}

Relative growth rate $\left(\mathrm{g}^{-1} \mathrm{~m}^{2}\right.$ day $\left.^{-1}\right)$ was estimated by using the following formula suggested by Hoffmann and Poorter (2002) [12].

$$
\mathrm{RGR}=\frac{\log W 2-W 1}{t 2-t 1}
$$

\section{Where}

Log = natural logarithm

$\mathrm{t}_{1}=$ time one (in days)

$\mathrm{t}_{2}=$ time two (in days)

$\mathrm{W}_{1}=$ Dry weight of plant at time $\mathrm{t} 1$ (in grams)

$\mathrm{W}_{2}=$ Dry weight of plant at time $\mathrm{t} 2$ (in grams)

$\log _{\mathrm{e}}$ value $=0.4342945$

\section{Net assimilation rate (NAR)}

Indirectly it shows the rate of net photosynthesis was estimated at different intervals of period and expressed in gram of dry matter per meter row length per day by using the following formula given by Gregory (1917) ${ }^{[11]}$.

$$
\mathrm{NAR}=\left(\mathrm{W}_{2}-\mathrm{W}_{1}\right)\left(\log _{\mathrm{e}} \mathrm{L}_{2}-\log _{\mathrm{e}} \mathrm{L}_{1}\right) /\left(\mathrm{t}_{2}-\mathrm{t}_{1}\right)\left(\mathrm{L}_{2}-\mathrm{L}_{1}\right)
$$

\section{Where}

$\mathrm{L}_{1}=$ Leaf area at a time one

$\mathrm{L}_{2}=$ Leaf area at a time two

$\mathrm{W}_{1=}$ Dry weight of plant at time one (in grams)

$\mathrm{W}_{2}=$ Dry weight of plant at time two (in grams)

$\mathrm{t}_{1}=$ Time one (in days)

$\mathrm{t}_{2}=$ Time two (in days)

$\mathrm{W}_{1}=$ Dry weight of plant at time one (in grams)

$\mathrm{W}_{2}=$ Dry weight of plant at time two (in grams)

\section{Ear length (cm.)}

Five ears were randomly selected from the sampled plants at harvest and length was measured from the base to the tip of the ear, including awn.

\section{0 grain weight $(\mathrm{g})$}

From the grain sample of each net plot, 1000 grains were selected at random and their weight was recorded in grams (g).

\section{Soil analysis after harvest of crop}

Random soil samples were collected from each experiment plot from depth of 0-15 cm after harvest of crop during both years. These soil samples further brought in lab followed by oven drying, crushed and passed through $2.0 \mathrm{~mm}$ sieve. These samples were used for analyzing $\mathrm{pH}, \mathrm{EC}, \mathrm{OC}, \mathrm{N}, \mathrm{P}, \mathrm{K}$, and $\mathrm{Zn}$ by following their standard procedure.

\section{Statistical analysis}

The analysis and interpretation of data was done using the Fischer's method of analysis of variance technique as described by Gomez and Gomez (1984) ${ }^{[10]}$. The level of significance used in ' $F$ ' and ' $t$ ' test was P-0.05 and critical difference values were calculated wherever the ' $F$ ' test as significant.

\section{Results and Discussion \\ Crop growth rate $\left(\mathrm{g} \mathrm{m}^{-2}\right.$ day $\left.^{-1}\right)$ \\ Irrigation scheduling}

It is apparent from 2014-15 data presented in Table 1 that, crop growth rate (CGR) had shown mixed response to irrigation schedules during both the years. CGR at 30 DAS was found non-significant. Highest CGR (2.29 $\mathrm{g} \mathrm{m}^{-2}$ day $\left.^{-1}\right)$ was recorded in $\mathrm{I}_{2}$ at $60 \mathrm{DAS}$ was significantly superior over other treatments. At harvest, highest CGR (2.67 $\mathrm{g} \mathrm{m}^{-2}$ day $\left.^{-1}\right)$ was recorded in $\mathrm{I}_{2}$ treatment.

During second year (2015-16), highest CGR (0.59 $\mathrm{g} \mathrm{m}^{-2}$ day $\left.^{-1}\right)$ at $30 \mathrm{DAS}$, was found $\mathrm{I}_{2}$ over other treatments. Same trend was found at 60 DAS. CGR at 90 DAS and harvest was found non-significant.

\section{Zinc fertilization}

Significant variation in crop growth rate was observed in response to different zinc fertilization treatment during both the years of experiments.

During 2014-15, highest CGR $\left(0.66 \mathrm{~g} \mathrm{~m}^{-2}\right.$ day $\left.^{-1}\right)$ at $30 \mathrm{DAS}$ was recorded in $\mathrm{Zn}_{4}\left(10 \mathrm{~kg} \mathrm{Zn} \mathrm{ha}{ }^{-1}\right.$ as basal $+0.25 \% \mathrm{ZnSO}_{4}$ foliar spray at $\mathrm{Z} 45+0.25 \%$ spray at $\mathrm{Z} 71$ ) which was at par to $\mathrm{Zn}_{3}$ and $\mathrm{Zn}_{5}$. Same trend was found at 60 DAS with highest CGR (2.20 m-1 day $\left.^{-1}\right)$ in $\mathrm{Zn}_{4}$. At 90 DAS highest CGR (2.92 g $\mathrm{m}^{-2}$ day $^{-1}$ ) was recorded in $\mathrm{Zn}_{4}$ and it was at par with $\mathrm{Zn}_{5}$. CGR at harvest was recorded non-significant.

Same trend was observed during succeeding year also for CGR as influenced by zinc fertilization. Highest CGR (0.62 g $\mathrm{m}^{-2}$ day $^{-1}$ ) at 30 DAS was recorded in $\mathrm{Zn}_{4}$ which was at par to $\mathrm{Zn}_{2}, \mathrm{Zn}_{3}$ and $\mathrm{Zn}_{5}$ treatments. At 60 DAS, highest CGR (2.18 g $\mathrm{m}^{-1}$ day $^{-1}$ ) was found in $\mathrm{Zn}_{4}$ treatment. But at harvest CGR was found non-significant. Meanwhile lowest CGR was found in $\mathrm{Zn}_{1}$ (control) during all stages in both years of experiments.

\section{Relative growth rate $\left(\mathrm{g} \mathrm{m}^{-2}\right.$ day $\left.^{-1}\right)$ \\ Irrigation scheduling}

The summary of data on relative growth rate (RGR) at different days of observation is presented in Table 1. In general, relative growth rate was decreased as the growth progressed up to harvest during both the years. The RGR found non-significant at all stages of intervals, except at 60 90 DAS interval during 2014-15 in response to irrigation scheduling and highest RGR $\left(0.011 \mathrm{~g} \mathrm{~m}^{-2}\right.$ day $\left.^{-1}\right)$ was recorded in $\mathrm{I}_{4}$ (CRI + Milking + Dough) irrigation treatment. It was further at par to $I_{1}$ and $I_{3}$ irrigation treatments.

During 2015 and 2016 also, RGR was found non-significant in all treatments at all observation intervals.

\section{Zinc fertilization}

In contrast to irrigation scheduling, marked variation in RGR was observed due to different zinc fertilization management practices.

Significantly higher RGR $\left(0.026 \mathrm{~g} \mathrm{~m}^{-2}\right.$ day $\left.^{-1}\right)$ was found in control $\left(\mathrm{Zn}_{1}\right)$ treatment at $30-60$ duration during 2014 and 2015 years. Meanwhile at 60-90 DAS and at 90- at harvest interval, it was found non- significant during both years. Meanwhile interaction effect between irrigation scheduling and zinc fertilization was found significant during 30-60 DAS interval of 2016 year and during both years at 60-90 DAS and 90- at harvest intervals.

\section{Net assimilation rate $\left(\mathrm{g} \mathrm{m}^{-2} \mathrm{day}^{-1}\right)$ \\ Irrigation scheduling}

The summary of data on net assimilation rate (NAR) at different days of observation is presented in Table 3. In general, NAR was decreased as the growth progressed up to harvest during both the years. The net assimilation found nonsignificant at all the stages of the growth during both the years. 


\section{Zinc fertilization}

Marked variation in net assimilation rate was not observed due to different zinc fertilization practices and NAR was found non-significant at all the growth stages during both the years of experiment.

\section{Ear length (cm) Irrigation scheduling}

From the scanning of data on ear length, presented in Table 2 reveals that, longest ear length $(11.78 \mathrm{~cm})$ was recorded in $\mathrm{I}_{2}$ $(\mathrm{CRI}+$ Late Jointing + Milking) treatment of irrigation scheduling and was at par to $\mathrm{I}_{1}(10.86 \mathrm{~cm})$. Lowest value of ear length was recorded in $\mathrm{I}_{4}(9.93 \mathrm{~cm})$ during 2014-15.

During second year, 2015-16, highest value of ear length $(13.09 \mathrm{~cm})$ was recorded in $\mathrm{I}_{2}$ treatment of irrigation scheduling followed by $\mathrm{I}_{3}$ and $\mathrm{I}_{4}$. Lowest ear length $(10.84$ $\mathrm{cm}$ ) was recorded in $\mathrm{I}_{1}$.

\section{Zinc fertilization}

It is evident from the data that, application of $10 \mathrm{~kg} \mathrm{Zn} \mathrm{ha}^{-1}$ at basal $+0.25 \% \mathrm{ZnSO}_{4}$ foliar spray at $\mathrm{Z} 45+0.25 \%$ at $\mathrm{Z} 71$ $\left(\mathrm{Zn}_{4}\right)$ produced longest ear length $(11.91 \mathrm{~cm})$ which was at par to $\mathrm{Zn}_{2}$ and $\mathrm{Zn}_{3}$ during 2014-15. Lowest ear length (9.56 $\mathrm{cm})$ was recorded in control treatment.

Same trend was also found during 2015-16 year. Highest ear length $(12.70 \mathrm{~cm})$ was recorded in $\mathrm{Zn}_{4}$ treatment while lowest value $(10.76 \mathrm{~cm})$ was found in control.

\section{Thousand grain weight $(\mathrm{g})$}

Data pertaining to 1000 grain weight as influenced by different treatments are summarized in Table no 3. Close scanning of data revealed that, significant variation in 1000 grain weight due to irrigation schedules and zinc fertilization was recorded during both the years.

During 2014-15 year of experiment, 1000 grain weight (32.01 g) of wheat obtained from irrigation scheduling at CRI + Late Jointing + Milking was significantly superior over other treatments. Lowest 1000 grain weight $(27.12 \mathrm{~g})$ was recorded in irrigation scheduling at CRI + Milking+ Late Jointing stages.

Same trend was also repeated during successive year of experiment. Highest 1000 grain weight (32.04 g) was recorded in $\mathrm{I}_{2}$ treatment. Lowest value of 1000 grain weight $(28.08 \mathrm{~g})$ was found in $\mathrm{I}_{4}$ treatment.

\section{Zinc fertilization}

In general the zinc management practices produced significantly highest 1000 grain weight. In treatment of $10 \mathrm{~kg}$ $\mathrm{Zn} \mathrm{ha}^{-1}$ at basal $+0.25 \% \mathrm{ZnSO}_{4}$ foliar spray at $\mathrm{Z} 45+0.25 \%$ spray at $\mathrm{Z} 71\left(\mathrm{Zn}_{4}\right)$ produced maximum 1000 grain weight (31.38 g) which was at par to $\mathrm{Zn}_{2}, \mathrm{Zn}_{3}$ and $\mathrm{Zn}_{5}$ during 2014-15 year. Lowest 1000 grain weight $(25.49 \mathrm{~g})$ was found in control.

During second year of experiment, same trend was also recorded. Highest value of 1000 grain weight $(32.02 \mathrm{~g})$ was recorded in $\mathrm{Zn}_{4}$, which was at par to $\mathrm{Zn}_{2}$ and $\mathrm{Zn}_{3}$. Meanwhile, $\mathrm{Zn}_{1}$ recorded lowest value of 1000 grain weight (26.43).

Longest ear length $(11.78$ and $13.90 \mathrm{~cm})$, highest grain count (45.35 and 46.08) and 1000 grain weight (32.01 and $32.04 \mathrm{~g}$ ) were recorded during 2014-15 and 2015-16 year, respectively in irrigation schedule of CRI + Late Jointing + Milking. It might be increased due to irrigation scheduled at Late Jointing stage of wheat. Formation of ear is related to number of productive or effective tillers and favourable condition for the formation of more number of productive tillers. It includes, increase in $\mathrm{CO}_{2}$ assimilation rate, late senescence of flag leaf and translocation of photosynthates (Bhat et al., 2004) ${ }^{[5]}$ from source to sink, whose cumulative effect resulted in production of higher number of longer spike length, number of grains per spike and test weight. Higher weight of grains per ear is attributed mainly to more number of grains per ear and 1000 grain weight. Irrigation at milking might be helped to accumulate more photosynthates in sink (grain) and more 1000 grain weight (32.01 and $32.04 \mathrm{~g}$ respectively). These findings are also supported by Singh et al., 1980 [19, 22]. Besides, it might also be due to irrigation scheduling at CRI + Late Jointing + milking caused increase of dry matter production under higher moisture regimes and its further partitioning into spikes. It may turns into heavier spike, hence, more number of grains spike ${ }^{-1}$ (Idnani and Kumar, 2012) ${ }^{[13]}$. Application of zinc showed varied significant response to different yield parameters, although mostly controlled by genetic factors. Zinc applied @ $10 \mathrm{~kg} \mathrm{Zn} \mathrm{ha}^{-1}$ at basal $+0.25 \%$ $\mathrm{ZnSO}_{4}$ foliar spray at $\mathrm{Z} 45+0.25 \%$ spray at $\mathrm{Z} 71$ resulted longest length of ear $(11.91$ and $12.70 \mathrm{~cm})$, highest number of grains per ear (44.86 and 45.23) and 1000 grain weight (31.58 and 32.02 g) during 2014-15 and 2015-16 year, respectively. The increase in length of ear in response to zinc management might be correlated to better nutrition of panicle primordia (Ali et al, 2011, Shah et al, 2011, Basit et al. 2005 and Jan et $a l, 2013)^{[1,2,4,20]}$ which may results in improvement in yield parameters. Similar results related to improvement in spike length, effective tillers plant ${ }^{-1}$ and number of grains plant ${ }^{-1}$ in response to application of zinc have been reported by Ali et al. (2009) [1], Reddy and Bhardwaj (1989) [18], Islam et al (1999) ${ }^{[14]}$ and Genc et al (2006) ${ }^{[9]}$. Meanwhile, lowest length of ear $(9.56$ and $10.76 \mathrm{~cm})$, highest number of grains per ear (34.29 and 37.33) and 1000 grain weight (25.49 and $26.43 \mathrm{~g}$ ) were recorded during 2014-15 and 2015-16 year, respectively.

\section{Soil pH, EC and organic carbon after harvest of crop}

The data related to $\mathrm{pH}, \mathrm{EC}$ and organic carbon in soil as influenced by irrigation scheduling and zinc fertilization has been presented in Table 4.40

\section{Irrigation scheduling}

Among chemical properties, $\mathrm{pH}, \mathrm{EC}$ and organic carbon were found non-significant by the irrigation scheduling during both the years of experimentation.

\section{Zinc fertilization}

The perusal of data revealed that, zinc fertilization had also found non-significant effect on $\mathrm{pH}, \mathrm{EC}$ and organic carbon during 2015-16 and 2015-16 seasons of crop growth.

\section{Zn content in soil after harvest of crop}

The data pertained to $\mathrm{Zn}$ content in soil was influenced by irrigation scheduling and zinc fertilization has been presented in Table 4.

\section{Irrigation scheduling}

Non-significant effect was found for $\mathrm{Zn}$ content in soil during both years in response to irrigation scheduling.

\section{Zinc fertilization}

From scrutiny of the data it revealed that, effect of zinc fertilization on $\mathrm{Zn}$ content in soil was recorded statistically significant on during 2014-15. Highest soil Zn (0.52 $\left.\mathrm{mg} \mathrm{kg}^{-1}\right)$ was found in $\mathrm{Zn}_{5}\left(10 \mathrm{~kg} \mathrm{Zn} \mathrm{ha}^{-1}\right.$ at basal $+0.25 \% \mathrm{ZnSO}_{4}$ foliar spray at $\mathrm{Z} 60+0.25 \%$ spray at $\mathrm{Z} 83$ ) treatment, followed by 
$\mathrm{Zn}_{4}$ (0.46 mg kg-1). However; lowest $\mathrm{Zn}\left(0.40 \mathrm{mg} \mathrm{kg}{ }^{-1}\right)$ content in soil was found in $\mathrm{Zn}_{1}$ (control) treatment.

Similar trend was also found during 2015-16 season with highest soil $\mathrm{Zn}\left(0.50 \mathrm{mg} \mathrm{kg}^{-1}\right)$ was found in $\mathrm{Zn}_{5}$ treatment. Meanwhile, lowest soil $\mathrm{Zn}\left(0.39 \mathrm{mg} \mathrm{kg}^{-1}\right)$ was recorded in $\mathrm{Zn}_{1}$.

Table 2: Effect of irrigation scheduling and zinc fertilization on crop growth rate (CGR) of wheat

\begin{tabular}{|c|c|c|c|c|c|c|c|c|}
\hline \multirow{3}{*}{ Treatments } & \multicolumn{8}{|c|}{ CGR $\left(\mathrm{gg}^{-1} \mathrm{~m}^{-2}\right)$} \\
\hline & \multicolumn{2}{|c|}{30 DAS } & \multicolumn{2}{|c|}{60 DAS } & \multicolumn{2}{|c|}{90 DAS } & \multicolumn{2}{|c|}{ At harvest } \\
\hline & 2015 & 2016 & 2015 & 2016 & 2015 & 2016 & 2015 & 2016 \\
\hline \multicolumn{9}{|c|}{ Irrigation scheduling (I) } \\
\hline $\mathrm{I}_{1}$ & 0.55 & 0.53 & 2.09 & 2.08 & 2.44 & 2.50 & 2.04 & 2.17 \\
\hline $\mathrm{I}_{2}$ & 0.61 & 0.59 & 2.29 & 2.19 & 2.31 & 2.55 & 2.67 & 2.54 \\
\hline $\mathrm{I}_{3}$ & 0.53 & 0.49 & 1.92 & 1.87 & 2.41 & 2.53 & 2.00 & 1.91 \\
\hline $\mathrm{I}_{4}$ & 0.54 & 0.48 & 1.74 & 1.72 & 2.55 & 2.50 & 1.90 & 2.08 \\
\hline S.Em \pm & 0.03 & 0.03 & 0.08 & 0.07 & 0.16 & 0.16 & 0.16 & 0.23 \\
\hline $\mathrm{CD}(0.05)$ & NS & 0.53 & 0.22 & 0.21 & NS & $\mathrm{NS}$ & 0.44 & $\mathrm{NS}$ \\
\hline \multicolumn{9}{|c|}{ Zinc fertilization (Zn) } \\
\hline $\mathrm{Zn}_{1}$ & 0.36 & 0.34 & 1.79 & 1.76 & 2.27 & 2.27 & 2.01 & 2.01 \\
\hline $\mathrm{Zn}_{2}$ & 0.54 & 0.52 & 2.09 & 2.07 & 2.15 & 2.58 & 2.42 & 2.17 \\
\hline $\mathrm{Zn}_{3}$ & 0.60 & 0.54 & 2.01 & 1.95 & 2.26 & 2.34 & 2.19 & 2.27 \\
\hline $\mathrm{Zn}_{4}$ & 0.66 & 0.62 & 2.20 & 2.18 & 2.92 & 2.94 & 1.91 & 2.08 \\
\hline $\mathrm{Zn}_{5}$ & 0.62 & 0.60 & 1.96 & 1.87 & 2.53 & 2.48 & 2.15 & 2.35 \\
\hline S.Em \pm & 0.04 & 0.04 & 0.09 & 0.08 & 0.18 & 0.18 & 0.17 & 0.26 \\
\hline $\mathrm{CD}(0.05)$ & 0.11 & 0.11 & 0.24 & 0.24 & 0.51 & 2.27 & NS & NS \\
\hline IxZN & NS & NS & NS & NS & $\mathrm{S}$ & $\mathrm{S}$ & $\mathrm{S}$ & $\mathrm{S}$ \\
\hline
\end{tabular}

$\mathrm{I}_{1}-\mathrm{CRI}+$ Late tillering + Flowering

$\mathrm{I}_{2}-\mathrm{CRI}+$ Late Jointing + Milking

$\mathrm{I}_{3}-\mathrm{CRI}+$ Flowering + Dough

$\mathrm{I}_{4}-\mathrm{CRI}+$ Milking + Dough

\section{$\mathrm{Zn}_{1}-0 \mathrm{~kg} \mathrm{Zn} \mathrm{ha}{ }^{-1}$ (Control)}

$\mathrm{Zn}_{2}-5 \mathrm{~kg} \mathrm{Zn} \mathrm{ha}^{-1}$ at basal $+0.25 \% \mathrm{ZnSO}_{4}$ foliar spray at $\mathrm{Z} 45+0.25 \%$ at $\mathrm{Z} 71$

$\mathrm{Zn}_{3}-5 \mathrm{~kg} \mathrm{Zn} \mathrm{ha}{ }^{-1}$ at basal $+0.25 \% \mathrm{ZnSO}_{4}$ foliar spray at $\mathrm{Z} 60+0.25 \%$ spray at $\mathrm{Z} 83$

$\mathrm{Zn}_{4}-10 \mathrm{~kg} \mathrm{Zn} \mathrm{ha}^{-1}$ at basal $+0.25 \% \mathrm{ZnSO}_{4}$ foliar spray at $\mathrm{Z} 45+0.25 \%$ spray at $\mathrm{Z} 71$

$\mathrm{Zn}_{5}-10 \mathrm{~kg} \mathrm{Zn} \mathrm{ha}^{-1}$ at basal $+0.25 \% \mathrm{ZnSO}_{4}$ foliar spray at $\mathrm{Z} 60+0.25 \%$ spray at $\mathrm{Z} 83$

Table 3: Effect of irrigation scheduling and zinc fertilization on relative growth rate (RGR) of wheat

\begin{tabular}{|c|c|c|c|c|c|c|}
\hline \multirow{3}{*}{ Treatments } & \multicolumn{6}{|c|}{ RGR $\left(g^{-1}\right.$ day $\left.^{-1}\right)$} \\
\hline & \multicolumn{2}{|c|}{ 30-60 DAS } & \multicolumn{2}{|c|}{ 60-90 DAS } & \multicolumn{2}{|c|}{ 90-harvest } \\
\hline & 2015 & 2016 & 2015 & 2016 & 2015 & 2016 \\
\hline \multicolumn{7}{|c|}{ Irrigation scheduling (I) } \\
\hline $\mathrm{I}_{1}$ & 0.023 & 0.024 & 0.010 & 0.010 & 0.0050 & 0.005 \\
\hline $\mathrm{I}_{2}$ & 0.024 & 0.023 & 0.008 & 0.009 & 0.0063 & 0.006 \\
\hline $\mathrm{I}_{3}$ & 0.023 & 0.023 & 0.010 & 0.011 & 0.0050 & 0.005 \\
\hline $\mathrm{I}_{4}$ & 0.021 & 0.022 & 0.011 & 0.011 & 0.0048 & 0.005 \\
\hline S.Emt & 0.001 & 0.001 & 0.001 & 0.001 & 0.0005 & 0.001 \\
\hline $\mathrm{CD}(0.05)$ & NS & NS & 0.002 & NS & NS & NS \\
\hline \multicolumn{7}{|c|}{ Zinc fertilization (Zn) } \\
\hline $\mathrm{Zn}_{1}$ & 0.026 & 0.026 & 0.011 & 0.011 & 0.006 & 0.006 \\
\hline $\mathrm{Zn}_{2}$ & 0.023 & 0.024 & 0.009 & 0.010 & 0.006 & 0.005 \\
\hline $\mathrm{Zn}_{3}$ & 0.021 & 0.022 & 0.009 & 0.010 & 0.005 & 0.006 \\
\hline $\mathrm{Zn}_{4}$ & 0.022 & 0.022 & 0.010 & 0.010 & 0.004 & 0.005 \\
\hline $\mathrm{Zn} 5$ & 0.021 & 0.021 & 0.010 & 0.010 & 0.005 & 0.006 \\
\hline S.Em \pm & 0.001 & 0.001 & 0.001 & 0.001 & 0.001 & 0.001 \\
\hline $\mathrm{CD}(0.05)$ & 0.003 & 0.003 & NS & NS & NS & NS \\
\hline IxZN & NS & $\mathrm{S}$ & S & S & S & S \\
\hline \multicolumn{7}{|l|}{$\begin{array}{l}\mathrm{I}_{1}-\mathrm{CRI}+\text { Late Tillering + Flowerin } \\
\mathrm{I}_{2}-\mathrm{CRI}+\text { Late Jointing + Milking } \\
\mathrm{I}_{3}-\mathrm{CRI}+\text { Flowering + Dough } \\
\mathrm{I}_{4}-\mathrm{CRI}+\text { Milking + Dough }\end{array}$} \\
\hline \multicolumn{7}{|c|}{ Table 4: Effect of irrigation scheduling and zinc fertilization on net assimilation rate (NAR) of wheat } \\
\hline \multirow[t]{2}{*}{ Treatments } & \multicolumn{2}{|c|}{30 DAS } & \multicolumn{2}{|c|}{60 DAS } & \multicolumn{2}{|c|}{90 DAS } \\
\hline & 2015 & 2016 & 2015 & 2016 & 2015 & 2016 \\
\hline \multicolumn{7}{|c|}{ Irrigation scheduling (I) } \\
\hline $\mathrm{I}_{1}$ & 0.054 & 0.057 & 0.039 & 0.039 & 0.030 & 0.031 \\
\hline $\mathrm{I}_{2}$ & 0.059 & 0.064 & 0.042 & 0.044 & 0.029 & 0.030 \\
\hline $\mathrm{I}_{3}$ & 0.060 & 0.063 & 0.037 & 0.037 & 0.030 & 0.032 \\
\hline $\mathrm{I}_{4}$ & 0.063 & 0.065 & 0.035 & 0.035 & 0.029 & 0.030 \\
\hline S.Em \pm & 0.005 & 0.006 & 0.001 & 0.002 & 0.002 & 0.001 \\
\hline $\mathrm{CD}(0.05)$ & NS & NS & NS & NS & NS & NS \\
\hline
\end{tabular}




\begin{tabular}{|c|c|c|c|c|c|c|}
\hline \multicolumn{7}{|c|}{ Zinc fertilization (Zn) } \\
\hline$Z_{1}$ & 0.050 & 0.054 & 0.038 & 0.039 & 0.029 & 0.029 \\
\hline $\mathrm{Zn}_{2}$ & 0.057 & 0.062 & 0.040 & 0.040 & 0.028 & 0.030 \\
\hline $\mathrm{Zn}_{3}$ & 0.067 & 0.068 & 0.039 & 0.039 & 0.029 & 0.029 \\
\hline $\mathrm{Zn}_{4}$ & 0.060 & 0.062 & 0.039 & 0.041 & 0.032 & 0.033 \\
\hline $\mathrm{Zn}_{5}$ & 0.061 & 0.065 & 0.036 & 0.036 & 0.031 & 0.032 \\
\hline $\mathrm{S} . \mathrm{Em} \pm$ & 0.005 & 0.007 & 0.001 & 0.003 & 0.002 & 0.001 \\
\hline $\mathrm{CD}(0.05)$ & $\mathrm{NS}$ & $\mathrm{NS}$ & $\mathrm{NS}$ & $\mathrm{NS}$ & $\mathrm{NS}$ & $\mathrm{NS}$ \\
\hline $\mathrm{IxZN}$ & $\mathrm{NS}$ & $\mathrm{NS}$ & $\mathrm{NS}$ & $\mathrm{NS}$ & $\mathrm{S}$ & $\mathrm{S}$ \\
\hline
\end{tabular}

$\mathrm{I}_{1}-\mathrm{CRI}+$ Late Tillering + Flowering

$\mathrm{I}_{2}-\mathrm{CRI}+$ Late Jointing + Milking

$\mathrm{I}_{3}-\mathrm{CRI}+$ Flowering + Dough

$\mathrm{I}_{4}-\mathrm{CRI}+$ Milking + Dough
$\mathrm{Zn}_{1}-0 \mathrm{~kg} \mathrm{Zn} \mathrm{ha-1}$ (Control)

$\mathrm{Zn}_{2}-5 \mathrm{~kg} \mathrm{Zn} \mathrm{ha}^{-1}$ at basal $+0.25 \% \mathrm{ZnSO}_{4}$ foliar spray at $\mathrm{Z} 45+0.25 \%$ at $\mathrm{Z} 71$

$\mathrm{Zn}_{3}-5 \mathrm{~kg} \mathrm{Zn} \mathrm{ha}{ }^{-1}$ at basal $+0.25 \% \mathrm{ZnSO}_{4}$ foliar spray at $\mathrm{Z} 60+0.25 \%$ spray at $\mathrm{Z} 83$

$\mathrm{Zn}_{4}-10 \mathrm{~kg} \mathrm{Zn} \mathrm{ha}{ }^{-1}$ at basal $+0.25 \% \mathrm{ZnSO}_{4}$ foliar spray at $\mathrm{Z} 45+0.25 \%$ spray at $\mathrm{Z} 71$

$\mathrm{Zn} 5-10 \mathrm{~kg} \mathrm{Zn} \mathrm{ha}^{-1}$ at basal $+0.25 \% \mathrm{ZnSO}_{4}$ foliar spray at $\mathrm{Z} 60+0.25 \%$ spray at $\mathrm{Z} 83$

Table 5: Effect of irrigation scheduling and zinc fertilization on soil chemical properties after harvest of crop

\begin{tabular}{|c|c|c|c|c|c|c|c|c|}
\hline \multirow{2}{*}{ Treatment } & \multicolumn{2}{|c|}{$\mathbf{p H}$} & \multicolumn{2}{|c|}{ EC } & \multicolumn{2}{|c|}{$\mathrm{OC}(\%)$} & \multicolumn{2}{|c|}{$\mathrm{Zn}\left(\mathrm{mg} \mathrm{kg}^{-1}\right)$} \\
\hline & 2015 & 2016 & 2015 & 2016 & 2015 & 2016 & 2015 & 2016 \\
\hline \multicolumn{9}{|c|}{ Irrigation scheduling (I) } \\
\hline $\mathrm{I}_{1}$ & 7.03 & 7.05 & 0.143 & 0.144 & 0.34 & 0.34 & 0.45 & 0.44 \\
\hline $\mathrm{I}_{2}$ & 6.97 & 6.99 & 0.143 & 0.144 & 0.34 & 0.34 & 0.44 & 0.43 \\
\hline $\mathrm{I}_{3}$ & 6.85 & 6.89 & 0.143 & 0.143 & 0.35 & 0.35 & 0.45 & 0.43 \\
\hline $\mathrm{I}_{4}$ & 6.95 & 6.93 & 0.143 & 0.144 & 0.33 & 0.33 & 0.46 & 0.44 \\
\hline S.Em \pm & 0.10 & 0.09 & 0.001 & 0.001 & 0.01 & 0.01 & 0.01 & 0.01 \\
\hline $\mathrm{CD}(0.05)$ & NS & NS & NS & NS & NS & NS & NS & NS \\
\hline \multicolumn{9}{|c|}{ Zinc fertilization (Zn) } \\
\hline $\mathrm{Zn}_{1}$ & 7.12 & 7.14 & 0.145 & 0.146 & 0.35 & 0.35 & 0.40 & 0.39 \\
\hline $\mathrm{Zn}_{2}$ & 6.98 & 6.97 & 0.141 & 0.142 & 0.33 & 0.33 & 0.43 & 0.43 \\
\hline $\mathrm{Zn}_{3}$ & 7.08 & 7.13 & 0.142 & 0.143 & 0.33 & 0.33 & 0.43 & 0.41 \\
\hline $\mathrm{Zn}_{4}$ & 6.90 & 6.93 & 0.142 & 0.143 & 0.34 & 0.34 & 0.48 & 0.46 \\
\hline $\mathrm{Zn}_{5}$ & 6.67 & 6.67 & 0.143 & 0.144 & 0.35 & 0.35 & 0.52 & 0.50 \\
\hline S.Emt & 0.11 & 0.10 & 0.001 & 0.001 & 0.01 & 0.01 & 0.01 & 0.01 \\
\hline $\mathrm{CD}(0.05)$ & NS & NS & NS & NS & NS & NS & 0.02 & 0.02 \\
\hline IxZN & NS & NS & NS & NS & NS & NS & $\mathrm{S}$ & $\mathrm{S}$ \\
\hline
\end{tabular}

$\mathrm{I}_{1}-\mathrm{CRI}+$ Late Tillering + Flowering

$\mathrm{I}_{2}-\mathrm{CRI}+$ Late Jointing + Milking

$\mathrm{I}_{3}-\mathrm{CRI}+$ Flowering + Dough

$\mathrm{I}_{4}-\mathrm{CRI}+$ Milking + Dough
$\mathrm{Zn}_{1}-0 \mathrm{~kg} \mathrm{Zn} \mathrm{ha}{ }^{-1}$ (Control)

$\mathrm{Zn}_{2}-5 \mathrm{~kg} \mathrm{Zn} \mathrm{ha}^{-1}$ at basal $+0.25 \% \mathrm{ZnSO}_{4}$ foliar spray at $\mathrm{Z} 45+0.25 \%$ at $\mathrm{Z} 71$

$\mathrm{Zn}_{3}-5 \mathrm{~kg} \mathrm{Zn} \mathrm{ha}{ }^{-1}$ at basal $+0.25 \% \mathrm{ZnSO}_{4}$ foliar spray at $\mathrm{Z} 60+0.25 \%$ spray at $\mathrm{Z} 83$

$\mathrm{Zn}_{4}-10 \mathrm{~kg} \mathrm{Zn} \mathrm{ha}{ }^{-1}$ at basal $+0.25 \% \mathrm{ZnSO}_{4}$ foliar spray at $\mathrm{Z} 45+0.25 \%$ spray at $\mathrm{Z} 71$

$\mathrm{Zn}_{5}-10 \mathrm{~kg} \mathrm{Zn} \mathrm{ha}{ }^{-1}$ at basal $+0.25 \% \mathrm{ZnSO}_{4}$ foliar spray at $\mathrm{Z} 60+0.25 \%$ spray at $\mathrm{Z} 83$

\section{Conclusion}

The results indicated that irrigation scheduling and zinc fertilization significantly influenced plant height, crop growth rate (CGR), ear length and test weight. There was no significant variation in $\mathrm{pH}, \mathrm{EC}$, organic carbon and zinc with the irrigation scheduling interval. Application of zinc had significant increase in zinc content in soil. However, there was non-significant effect of irrigation scheduling and zinc fertilization on relative growth rate (RGR), net assimilation rate (NAR). On the basis of findings of two years experimentation, irrigation scheduling at CRI + Late Jointing+ Milking and zinc fertilization@ $10 \mathrm{~kg} \mathrm{Zn} \mathrm{ha}^{-1}$ as basal $+0.25 \% \mathrm{ZnSO}_{4}$ foliar spray at $\mathrm{Z} 45+0.25 \%$ spray at $\mathrm{Z}$ 71 stages of wheat is recommended for wheat growth.

\section{References}

1. Ali A, Ahmad A, Syed WH, Khaliq T, Asif M, Aziz M, Mubeen M. Effects of nitrogen on growth and yield components of wheat. Science International (Lahore) 2011;23:331-332.

2. Ali S, Shah A, Arif M, Miraj G, Ali I, Sajjad M et al. Enhancement of wheat grain yield and yield components through foliar application of zinc and boron. Sarhad Journal of Agriculture 2009;25:15-19.

3. Alloway BJ. Zinc in soils and crop nutrition (2nd ed.). Brussels: International Zinc Association; Paris: International Fertilizer Industry Association 2008.
4. Basit A, Faisal MI, Gul A, Jaffar AK, Ahmad N. Studies of nitrogen use efficiency in wheat (Triticum aestivum L.) by split application at different growth Stages. Journal of Applied. Environmental. Science 2005;1:39-42.

5. Bhat NR, Al Messaie H, Suleiman HK, Al Mulla L, Christpher A, Ferin J, Thomas B. Polymer effectiveness at different temperature regimes under arid environmental conditions. World Journal of Agricultural Science 2004;2:429-434.

6. Cai X, Rosegrant M. World water productivity: current situation and future options. In: Kijne, J.W., Barker, R., Molden, D. (Eds.), Water productivity in agriculture: limits and opportunities for improvement. International Water Management Institute (IWMI), Colombo, Sri Lanka 2003, P163-178.

7. Cakmak I, Pfeiffer WH, McClafferty B. Biofortification of durum wheat with zinc and iron. Cereal Chemistry 2010;87:10-20.

8. El-Gawad A, EL-Habbal A, Edris A, Elham A, Dorgham. Effect of water stress during grain filling period and nitrogen fertilization on yield and its attributes of two wheat genotypes. Egypt Journal of Agronomy 1993;18:211-227.

9. Genc Y, McDonald GK, Graham RD. Contribution of different mechanisms to zinc efficiency in bread wheat during early vegetative stage. Plant Soil 2006;281:35367. 
10. Gomez KA, Gomez AA. Statistical Procedures for Agricultural research, $2^{\text {nd }}$ edition, A Wiley-Inter Science Publication, New York (USA) 1984, P196-211.

11. Gregory FG. Third annual report, experimental and research station, Chesnut 1917.

12. Hoffmann WA, Poorter H. Avoiding Bias in Calculations of Relative Growth Rate. Annals of Botany 2002;90:37.

13. Idnani LK, Kumar A. Performance of wheat (Triticum aestivum) under different irrigation schedules and sowing methods. Indian Journal of Agricultural Sciences 2012;83:37-40.

14. Islam MR, Islam MS, Jahirhuddin M, Hoque MS. Effect of sulphur, zinc and boron on yield, yield components and nutrients uptake of wheat. Pakistan Journal Sci Indus Research 1999;42:137-40.

15. Khoshgoftarmanesh AH, Schulin R, Chaney RL, Daneshbakhsh B, Afyuni M. Micronutrient-efficient genotypes for crop yield and nutritional quality in sustainable agriculture. A review. Agronomy for Sustainable Development 2010;30:83-107.

16. Mehasen S, Gizawy N, Sharoba A, Soliman S, Khalil T. Yield and chemical composition of bread wheat cultivars as affected by some skipping irrigation. Minufiya Journal of Agriculture Research 2014;39:1-4.

17. Muhammad A, Haji K, Muhammad S. Performance of different wheat (Triticum aestivum L.) varieties under the agro-climatic conditions of Dera Ismail Khan. Sarhad Journal of Agriculture 1997;13:527-528.

18. Reddy, Bhardwaj RBL. Effect of nitrogen and phosphorous on growth and yield of wheat under limited and adequate irrigation. Indian Journal of Agronomy 1989;29:505-09.

19. Singh Y, Kukal S, Jat M, Sidhu H. Improving Water Productivity of Wheat-Based Cropping Systems in South Asia for Sustained Productivity. Sparks, D. (Ed.), Advances in Agronomy. Academic Press, Elsevier Inc 2014; $127: 157-258$.

20. Shah WA, Khan HU, Anwar S, Nawab K. Yield and yield components of wheat as affected by different seed rates and nitrogen levels. Sarhad Journal of Agriculture 2011;27:17-25.

21. Sharaan A, Abd EL-Samie, Gawad. Response of wheat varieties to some environmental influences. II-Effect of planting date and drought at different plant stages on yield and its components. 9th Conf. of Agronomy Menofiya, Egypt 2000;2(3):1-16.

22. Singh RP, Dhiman SD, Sharma HC. Performance of wheat varieties under limited water supply. Indian Journal of Agronomy 1980;25:259-262.

23. Watson DJ. The physiological basis of variation in yield. Advances in Agronomy 1952;4:101-145.

24. Welch RM. Zinc Concentrations and Forms in Plants for Humans and Animals, Kluwer, Dordrecht, The Netherlands 1993.

25. Zadoks J, Chang T, Konzak C. A decimal code for the growth stages of cereals. Weed Research 1974;6:415421. 